\title{
Effect of micronization on energy, starch and amino acid digestibilities in wheat for young pigs
}

\author{
S.X. Huang, W.C. Sauer ${ }^{1}$, L. Hargreaves, \\ M. Pickard ${ }^{2}$ and S. Li
}

\author{
Department of Agricultural, Food and Nutritional Science, \\ University of Alberta \\ Edmonton, Alberta, Canada T6G $2 P 5$
}

(Received 20 May 1997; accepted 19 August 1997)

\begin{abstract}
Studies were carried out to determine the effect of micronization (infrared processing) on the energy, starch and amino acid digestibilities in wheat. Six pigs (Canabrid $x$ Camborough) were weaned at 21 day of age and fitted with a simple T-cannula at the distal ileum on day 23 or 24 . The pigs were fed one of three diets consisting of ground wheat and soyabean meal, micronized wheat and soyabean meal, and maize starch and soyabean meal according to repeated Latin square design. The pigs were fed three times daily, cqual amounts at 8 -h intervals. The diets were supplied at a ratc of $5 \%$ (wt/wt) of body weight. The average body weight of the pigs was $9.2 \mathrm{~kg}$ at the start and $16.5 \mathrm{~kg}$ at the conclusion of the experiment. Faeces were collected for $48 \mathrm{~h}$ on day 6 and 7 and ileal digesta for $24 \mathrm{~h}$ on day 8 and 9. Chromic oxide was used as digestibility marker. The apparent ileal amino acid digestibilities in ground and micronized wheat were determined with the difference method. The apparent digestibilities of the indispensable amino acids were higher in micronized than ground wheat and ranged from 2.2 (arginine) to 12.2 (threonine) percentage units. The differences were significant $(\mathrm{P}<0.05)$ for histidine, lysine, phenylalanine and threonine. Micronization of wheat improved $(\mathrm{P}<0.05)$ the ileal digestibility of starch from 93.1 to $99.3 \%$. Micronization resulted in an increase in the digestion and absorption of energy in the small intestine and in a decrease in microbial fermentation of energy in the large intestine. These studies show a positive effect of micronization on the digestibilities of energy and amino acids in young pigs fed wheat.
\end{abstract}

KEY WORDS: micronization, wheat, digestibility, pigs

\footnotetext{
${ }^{1}$ Corresponding author

${ }^{2}$ InfraReady Products Limited. 850C 56th St.E., Saskatoon, SK, Canada S7K 5Y8
} 


\section{INTRODUCTION}

Wheat is often included in diets for young pigs and serves as a major source of energy and to a lesser extent of protein. The maturity of the digestive tract of growing and finishing pigs allows for efficient digestion of carbohydrates and protein in wheat. However, there is little information on the digestibilities in young pigs, in which the digestive system is not yet fully developed (BengalaFreire et al., 1988).

Several studies, in vitro or in vivo using rats, have been carried out to determine the effect of processing methods such as extrusion, drum-drying, extrusion and cooking on the nutritive value of wheat (Björck and Asp, 1984; Björck et al., 1984 $a, b$; Jideani et al., 1994). Depending on the severity of processing conditions, processing may have a beneficial or detrimental effect (Björck and Asp, 1983). Beneficial effects include gelatinization of starch, detrimental effects include Maillard reactions between protein and sugars.

The objectives of this study were to determine the effect of micronization (infrared processing) on the digestibilities of energy, starch, and amino acids in wheat fed to young pigs.

\section{MATERIAL AND METHODS}

\section{Animal trial procedures}

Six PIC (Pig Improvement Canada) barrows (Canabrid x Camborough), weaned at $3 \mathrm{wk}$ of age, were obtained from the University of Alberta Swine Research Unit. The average body weight $(\mathrm{BW})$ at weaning was $7.0 \mathrm{~kg}$. The barrows were housed individually in metabolism crates in a barn in which the temperature was maintained between 25 and $28^{\circ} \mathrm{C}$. The pigs had ad libitum access to a starter diet containing $18 \% \mathrm{CP}$ formulated to supply digestible energy and nutrients according to NRC (1988) recommendations. Water was freely available from a low-pressure drinking nipple.

The pigs were fitted with a simple T-cannula at the distal ileum, approximately $5 \mathrm{~cm}$ from the ileo-caecal sphincter, on day 6 and 7 after weaning. A detailed description of cannula preparation, surgery, pre-and post-operative care was previously provided by $\mathrm{Li}$ et al. (1994).

Following a 7-day recuperation period, the pigs were fed three experimental diets (Table 1) according to repeated Latin square design. Each experimental period was 9 days. The pigs were fed the experimental diets at a rate of $5 \%$ of the average BW of all pigs which was determined at the start of each experimental period. The average BW of the pigs were $9.2,11.0$ and $13.4 \mathrm{~kg}$ at the beginning of 
Composition of the experimental diets, \%

Diets $^{2}$

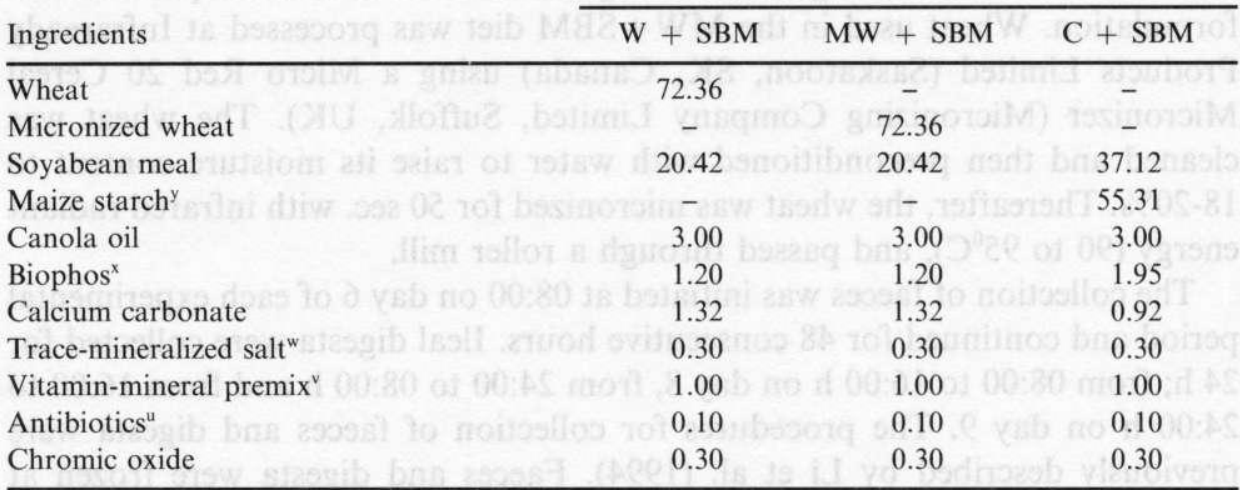

2 W + SBM: ground wheat-soyabean meal diet; MW + SBM: micronized wheat-soyabean meal diet; C + SBM: maize starch-soyabean meal diet

y St. Lawrence Starch Company Ltd., Mississauga, ON, Canada

x provided, \%: available phosphorus, $15-18$ and calcium, 24. Supplied by Continental Lime Ltd., Exshaw, AB, Canada

w Windsor Salt Co., Toronto, ON, Canada. Composition, \%: $\mathrm{NaCl}, 96.5 ; \mathrm{ZnO}, 0.4 ; \mathrm{FeCO}_{3}, 0.16$; $\mathrm{MnO}, 0.12 ; \mathrm{CuO}, 0.033 ; \mathrm{Ca}\left(\mathrm{IO}_{3}\right)_{2}, 0.007 ; \mathrm{CaO}, 0.004$

$\checkmark$ provided the following, per kg diet: vitamin $\mathrm{A}, 10,000 \mathrm{IU}$; vitamin $\mathrm{D}_{3}, 1.000 \mathrm{IU}$; vitamin $\mathrm{E}, 80 \mathrm{IU}$; vitamin $\mathrm{K}, 2.0 \mathrm{mg}$; vitamin $\mathrm{B}_{12}, 0.03 \mathrm{mg}$; riboflavin, $12 \mathrm{mg}$; niacin, $40 \mathrm{mg}$; d-pantothenic acid, $25 \mathrm{mg}$; choline, $1,000 \mathrm{mg}$; d-biotin, $0.25 \mathrm{mg}$; folic acid, $1.6 \mathrm{mg}$; thiamine, $3.0 \mathrm{mg}$; Ethoxyquin, 25 $\mathrm{mg}$; pyridoxine, $2.25 \mathrm{mg}$. Fe, $150 \mathrm{mg}$; Zn, $150 \mathrm{mg}$; Cu, $125 \mathrm{mg}$; I, $0.21 \mathrm{mg}$; Se, $0.3 \mathrm{mg}$. Supplied by Hoffmann-LaRoche Ltd., 2455 Meadowpine Blvd., Mississauga, ON, Canada

u veterinary LS-20 premix, provided, $\mathrm{g} / \mathrm{kg}$ mixture: Lincomycin hydrochloride 22 , Spectinomycin sulphate 22. Supplied by the Upjohn Company, Animal Health Division, Orangeville, ON, Canada

periods 1,2 and 3 , respectively. The $\mathrm{BW}$ at the conclusion of the experiment was $16.5 \mathrm{~kg}$. The total daily allowances were offered in three meals of equal amounts at 08:00, 16:00 and 24:00 h, respectively. All pigs usually consumed their meal allowance within $1 \mathrm{~h}$. The experimental diets consisted of ground wheat and soyabean meal $(\mathrm{W}+\mathrm{SBM})$, micronized wheat and soyabean meal $(\mathrm{MW}+\mathrm{SBM})$ and maize starch and soyabean meal $(\mathrm{C}+\mathrm{SBM})($ Table 1$)$. The diets were fed in mash form and formulated to contain $18 \% \mathrm{CP}$ (as-fed). The $\mathrm{W}+\mathrm{SBM}$ and $\mathrm{MW}+\mathrm{SBM}$ diets were formulated to contain $55 \% \mathrm{CP}$ from soyabean meal and $45 \%$ CP from wheat. Soyabean meal was solvent-extracted and contained $48.7 \%$ $\mathrm{CP}$ (as-fed). Canola oil was included in the diets to increase the digestible energy content to the level recommended by NRC (1988). Vitamins and minerals were also supplemented according to NRC (1988) standards. Chromic oxide was used as marker to determine the digestibilities of the parameters measured. 
The wheat used in this study was Canada Prairie Spring Red which is a classification of wheat that usually refers to common feed wheats. Wheat used in the $\mathrm{W}+\mathrm{SBM}$ diet was ground through a $0.3-\mathrm{mm}$ mesh screen prior to diet formulation. Wheat used in the MW + SBM diet was processed at Infraready Products Limited (Saskatoon, SK, Canada) using a Micro Red 20 Cereal Micronizer (Micronizing Company Limited, Suffolk, UK). The wheat was cleaned and then preconditioned with water to raise its moisture content to $18-20 \%$. Thereafter, the wheat was micronized for $50 \mathrm{sec}$. with infrared radiant energy $\left(90\right.$ to $\left.95^{\circ} \mathrm{C}\right)$, and passed through a roller mill.

The collection of faeces was initiated at 08:00 on day 6 of each experimental period and continued for 48 consecutive hours. Ileal digesta were collected for $24 \mathrm{~h}$; from $08: 00$ to $16: 00 \mathrm{~h}$ on day 8 , from $24: 00$ to $08: 00 \mathrm{~h}$ and from $16: 00$ to 24:00 $\mathrm{h}$ on day 9. The procedures for collection of faeces and digesta were previously described by $\mathrm{Li}$ et al. (1994). Faeces and digesta were frozen at $-28^{\circ} \mathrm{C}$ immediately following collection. Samples were pooled giving one sample of faeces and digesta for each pig in each period.

The animals used in this experiment were cared for in accordance with the guidelines established by CCAC (1984) and approved by the Faculty of Agriculture and Forestry Animal Care Committee of the University of Alberta.

\section{Chemical and statistical analysis}

Samples of the diets were taken each time when the meal allowances were weighed out and pooled for each dietary treatment. Faeces and digesta were freeze-dried and finely ground.

The dry matter content was determined according to AOAC (1990), crude protein with a Leco FP-428 Nitrogen Analyzer (Leco Corporation, St. Joseph, MI, U.S.A.). Analysis of NDF in the dietary ingredients were carried out according to principles outlined by Goering and van Soest (1970). Gross energy was determined using a Parr 1241 Adiabatic Bomb Calorimeter (Parr Instruments, Moline, IL, U.S.A.).

The contents of starch in the dietary ingredients, digesta and faeces were determined with the Megazyme total starch analysis procedure (thermostable a-amylase/amyloglucosidase method; Megazyme, Warriewood, Australia). Chromic oxide was measured according to Fenton and Fenton (1979).

For amino acid analyses, except for cysteine and methionine, approximately $0.1 \mathrm{~g}$ of sample was weighed into a screw-capped test tube and mixed with $3 \mathrm{ml}$ of $6 \mathrm{~N} \mathrm{HCL}$. The tubes were purged with nitrogen and then hydrolyzed in an oven at $110^{\circ} \mathrm{C}$ for $24 \mathrm{~h}$. The hydrolyzed samples were mixed with the internal standard, 
DL-amino-n-butyric acid, and centrifuged at $1,110 \mathrm{~g}$ for $15 \mathrm{~min}$ at $4^{\circ} \mathrm{C}$. The supernatant of the sample was analyzed according to Jones and Gilligan (1983) using a Varian 5000 high performance liquid chromatography system with a reverse-phase column and a Varian Fluorichrom detector (Varian Canada Inc., Mississauga, ON, Canada). This procedure was described in more detail by Sedgwick et al. (1991). The amino acids were derivatized with an o-phthaldialdehyde reagent solution. The mobile phase consisted of two solvents with

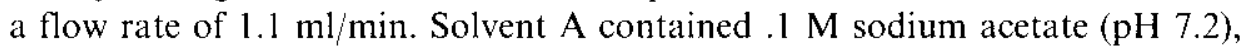
methanol, and tetrahydrofuran in a ratio of 90 to 5; solvent B was pure methanol. Peaks were recorded and integrated using the Ezchrom ${ }^{\mathrm{TM}}$ Chromatography Data System (version 2.12; Shimadzu Scientific Instruments Inc., Columbia, MD, U.S.A.). Methionine and cysteine were determined as methionine sulphone and cysteic acid after oxidation with $98 \%$ performic acid overnight according to AOAC (1990). The oxidized samples were dried according to procedures described by Dugan et al. (1992), then hydrolyzed and analyzed in the same manner as the other amino acids. Tryptophan and proline were not measured.

Analyses of ingredients and diets were carried out in triplicate; analyses of faeces and digesta in duplicate.

The apparent ileal and faecal digestibilities of dry matter, energy, starch, CP and amino acids in the experimental diets were determined using equation (1):

$$
D_{D}=100 \%-\left[\left(I_{D} \times A_{F}\right) /\left(A_{D} \times I_{F}\right)\right] \times 100 \%
$$

where $D_{D}$ is apparent digestibility of a nutrient in the assay diet $(\%), I_{D}$ is marker concentration in the assay diet $(\%), \mathrm{A}_{\mathrm{F}}$ is nutrient concentration in ileal digesta and faeces $(\%), A_{D}$ is nutrient concentration in the assay diet $(\%), I_{F}$ is marker concentration in ileal digesta or faeces $(\%)$.

By using soyabean meal as the basal feed ingredient, the apparent ileal digestibility values of $\mathrm{CP}$ and amino acids in $\mathrm{HB}$ and $\mathrm{MHB}$ were calculated by the difference method using equation (2):

$$
D_{A}=\left[D_{D}-\left(D_{B} \times S_{B}\right)\right] / S_{\Lambda}
$$

where $D_{A}$ is apparent digestibility of a nutrient in the assay feed ingredient (\%), $D_{D}$ is as defined previously, $D_{B}$ is apparent digestibility of a nutrient in the basal feed ingredient (\%), $S_{B}$ is the contribution level $(\%)$ of a nutrient in the basal ingredient to the assay diet, $S_{\Lambda}$ is the contribution level $(\%)$ of a nutrient in the assay ingredient to the assay diet.

Data were subjected to analysis of variance using the General Linear Model procedure of SAS (1990). Means of treatments were compared using the Student-Newman-Keuls multiple range test procedure. 


\section{RESULTS}

The piglets remained healthy and consumed their meal allowances throughout the experiment. Postmortem examinations, conducted at the conclusion of the experiment, revealed no adhesions or other intestinal abnormalities.

The chemical composition of ground and micronized wheat and the experimental diets are presented in Tables 2 and 3, respectively. The starch content was slightly lower in micronized wheat, by 2.5 percentage units. The analyzed values of $\mathrm{CP}$ and amino acids in the experimental diets were very close to the calculated values based on the analyzed values in ground wheat, micronized wheat and soyabean meal.

TABLE 2

Dry matter, neutral-detergent fibre (NDF), energy, starch, crude protein and amino acid content of the dietary ingredients, $\%$ ?

\begin{tabular}{|c|c|c|c|}
\hline \multirow[b]{2}{*}{ Item } & \multicolumn{3}{|c|}{ Ingredients ${ }^{y}$} \\
\hline & W & MW & SBM \\
\hline Dry matter & 87.6 & 88.7 & 88.7 \\
\hline NDF & 11.0 & 10.4 & 7.1 \\
\hline Energy, $\mathrm{MJ} \mathrm{kg}^{-1}$ & 18.4 & 18.5 & 19.7 \\
\hline Starch & 76.9 & 74.4 & 1.7 \\
\hline Crude protein & 13.1 & 13.3 & 55.0 \\
\hline \multicolumn{4}{|l|}{ Amino acids } \\
\hline \multicolumn{4}{|l|}{ Indispensable } \\
\hline arginine & 0.59 & 0.59 & 3.58 \\
\hline histidine & 0.30 & 0.30 & 1.35 \\
\hline isoleucine & 0.49 & 0.51 & 2.41 \\
\hline leucine & 0.94 & 0.95 & 3.92 \\
\hline lysine & 0.34 & 0.34 & 3.25 \\
\hline methionine & 0.25 & 0.24 & 0.68 \\
\hline phenylalanine & 0.60 & 0.62 & 2.55 \\
\hline threonine & 0.37 & 0.36 & 1.82 \\
\hline valine & 0.60 & 0.63 & 2.49 \\
\hline \multicolumn{4}{|l|}{ Dispensable } \\
\hline alanine & 0.50 & 0.53 & 2.53 \\
\hline aspartic acid & 0.72 & 0.73 & 5.76 \\
\hline cysteine & 0.31 & 0.30 & 0.54 \\
\hline glutamic acid & 4.15 & 4.36 & 9.76 \\
\hline glycine & 0.64 & 0.57 & 1.91 \\
\hline scrine & 0.60 & 0.63 & 2.51 \\
\hline tyrosine & 0.30 & 0.30 & 1.72 \\
\hline
\end{tabular}

a dry matter basis

${ }^{y} \mathrm{~W}$ : ground wheat; MW: micronized wheat; SBM: soyabean meal 
TABLE 3

Dry matter, neutral-detergent fibre (NDF), energy, starch, crude protein and amino acid content of the experimental diets, $\%^{*}$

\begin{tabular}{lccc}
\hline & \multicolumn{3}{c}{ Diets $^{y}$} \\
\cline { 2 - 4 } Iten & $\mathrm{W}+\mathrm{SBM}$ & $\mathrm{MW}+\mathrm{SBM}$ & $\mathrm{C}+\mathrm{SBM}$ \\
\hline Dry matter & 89.5 & 89.8 & 90.7 \\
NDF & 9.2 & 8.9 & 2.6 \\
Gross energy, MJ kg-1 & 18.7 & 18.9 & 18.5 \\
Starch & 54.9 & 53.5 & 58.9 \\
Crude protein & 20.4 & 20.6 & 19.8 \\
& & & \\
Amino acids & & & \\
Indispensable & & 1.14 & 1.30 \\
$\quad$ arginine & 1.14 & 0.49 & 0.50 \\
histidine & 0.48 & 0.85 & 0.88 \\
$\quad$ isoleucine & 0.84 & 1.47 & 1.42 \\
leucine & 1.45 & 0.90 & 1.18 \\
lysine & 0.89 & 0.31 & 0.23 \\
methionine & 0.31 & 0.96 & 0.93 \\
phenylalanine & 0.94 & 0.62 & 0.66 \\
threonine & 0.63 & 0.96 & 0.63 \\
$\quad$ valine & 0.94 & & \\
Dispensable & & 0.89 & 0.91 \\
$\quad$ alanine & 0.87 & 1.69 & 2.09 \\
aspartic acid & 1.68 & 0.32 & 0.18 \\
cysteine & 0.32 & 5.09 & 3.54 \\
glutamic acid & 4.92 & 0.80 & 0.69 \\
glycine & 0.84 & 0.96 & 0.91 \\
serine & 0.94 & 0.56 & 0.63 \\
tyrosine & 0.56 & & \\
\hline
\end{tabular}

"dry matter basis

${ }^{y}$ refer to Table 1

The apparent ileal digestibilities of dry matter, energy and starch were higher $(\mathrm{P}<0.05)$ in the $\mathrm{MW}+\mathrm{SBM}$ than $\mathrm{W}+\mathrm{SBM}$ diet (Table 4$)$. The differences were $10.7,10.7$ and 6.4 percentage units, respectively. The digestibilities of amino acids were higher in the MW + SBM than $\mathrm{W}+\mathrm{SBM}$ diet. Of the indispensable amino acids, except for methionine, the differences were significant $(\mathrm{P}<0.05)$, ranging from 2.5 (arginine) to 9.0 (threonine) percentage units. Of the dispensable amino acids, except for cysteine and glycine, the respective differences were significant $(\mathrm{P}<0.05)$ ranging from 4.0 (aspartic acid) to 6.3 (alanine).

As was the case for the ileal digestibilities, the apparent faecal digestibilities for dry matter, energy, $\mathrm{CP}$ and amino acids were higher in the $\mathrm{MW}+\mathrm{SBM}$ than $\mathrm{W}+$ SBM diet (Table 5). The differences were $1.1,1.6$ and 1.7 percentage units 
TABLE 4 Apparent ileal digestibilities of dry matter, energy, starch, crude protein and amino acids in the experimental diets, $\%$

\begin{tabular}{|c|c|c|c|c|}
\hline \multirow[b]{2}{*}{ Item } & \multicolumn{4}{|c|}{ Dicts $^{\prime}$} \\
\hline & $W+S B M$ & $\mathrm{MW}+\mathrm{SBM}$ & $\mathrm{C}+\mathrm{SBM}$ & SEM $^{y}$ \\
\hline Dry matter & $56.7^{\mathrm{c}}$ & $67.4^{\mathrm{b}}$ & $76.0^{a}$ & 1.29 \\
\hline Energy & $59.3^{c}$ & $70.0^{\mathrm{b}}$ & $79.5^{\mathrm{a}}$ & 1.25 \\
\hline Starch & $92.7^{\mathrm{b}}$ & $99.1^{4}$ & $98.4^{\mathrm{a}}$ & 0.60 \\
\hline Crude protein & 76.2 & 76.6 & 78.1 & 0.92 \\
\hline \multicolumn{5}{|l|}{ Amino acids } \\
\hline \multicolumn{5}{|l|}{ Indispensable } \\
\hline arginine & $87.7^{c}$ & $90.2^{b}$ & $92.3^{a}$ & 0.58 \\
\hline histidine & $85.8^{\mathrm{b}}$ & $89.8^{\mathrm{a}}$ & $90.8^{4}$ & 0.50 \\
\hline isoleucine & $83.3^{b}$ & $87.5^{\mathrm{a}}$ & $87.5^{4}$ & 0.61 \\
\hline leucine & $84.1^{\mathrm{b}}$ & $88.2^{\mathrm{a}}$ & $86.7^{\mathrm{a}}$ & 0.67 \\
\hline lysine & $79.8^{c}$ & $84.4^{b}$ & $88.1^{\mathrm{a}}$ & 0.82 \\
\hline methionine & 81.9 & 80.5 & 82.4 & 0.90 \\
\hline phenylalanine & $84.8^{\mathrm{b}}$ & $88.6^{\mathrm{a}}$ & $87.6^{\mathrm{a}}$ & 0.64 \\
\hline threonine & $71.4^{\mathrm{b}}$ & $80.4^{4}$ & $78.9^{\mathrm{a}}$ & 0.98 \\
\hline valine & $80.6^{b}$ & $86.0^{4}$ & $85.7^{\mathrm{d}}$ & 0.79 \\
\hline \multicolumn{5}{|l|}{ Dispensable } \\
\hline alanine & $77.2^{b}$ & $83.5^{\mathrm{a}}$ & $85.2^{4}$ & 0.75 \\
\hline aspartic acid & $81.3^{h}$ & $85.3^{\mathrm{a}}$ & $86.7^{\mathrm{al}}$ & 0.68 \\
\hline cysteine & 74.5 & 72.6 & 66.4 & 2.42 \\
\hline glutamic acid & $89.2^{\mathrm{b}}$ & $93.5^{\mathrm{a}}$ & $89.2^{\mathrm{b}}$ & 0.77 \\
\hline glycine & 69.8 & 79.3 & 74.0 & 2.37 \\
\hline serine & $82.2^{b}$ & $87.2^{\mathrm{a}}$ & $86.2^{\mathrm{a}}$ & 0.70 \\
\hline tyrosine & $82.5^{b}$ & $87.2^{\mathrm{a}}$ & $88.5^{\mathrm{a}}$ & 0.58 \\
\hline
\end{tabular}

"refer to Table 1

${ }^{y}$ standard error of the mean

$\mathrm{a}, \mathrm{b}, \mathrm{c}-\mathrm{P}<0.05$

for dry matter, energy and CP, respectively. The faecal digestibility of starch in both diets was $100 \%$. For the indispensable amino acids, the differences ranged from 0.5 (histidine) to 4.1 (methionine) percentage units; for the dispensable amino acids, the differences ranged from 0.2 (glutamic acid) to 2.4 (tyrosine) percentage units.

The effect of micronization on the disappearance of the parameters measured in the large intestine, expressed quantitatively as $\mathrm{g} \mathrm{kg}^{-1} \mathrm{DMI}$, is presented in Table 6. The disappearance of dry matter, energy and starch in the large intestine was lower $(\mathrm{P}<0.05)$ in pigs fed the $\mathrm{MW}+\mathrm{SBM}$ than the $\mathrm{W}+\mathrm{SBM}$ diet. For each of the experimental diets, there was a larger disappearance of the dispensable than indispensable amino acids. Of the dispensable amino acids, the disap- 
TABLE 5

Apparent faecal digestibilities of dry matter, energy, starch, crude protein and amino acids in the experimental diets, \%

\begin{tabular}{|c|c|c|c|c|}
\hline \multirow[b]{2}{*}{ Item } & \multicolumn{4}{|c|}{ Diets: } \\
\hline & $W+S B M$ & $\mathrm{MW}+\mathrm{SBM}$ & $\mathrm{C}+\mathrm{SBM}$ & SEM $^{y}$ \\
\hline Dry matter & $86.2^{\circ}$ & $87.3^{b}$ & $93.0^{\text {d }}$ & 0.27 \\
\hline Energy & $86.0^{\mathrm{c}}$ & $87.6^{b}$ & $94.4^{a}$ & 0.36 \\
\hline Starch & 100.0 & 100.0 & 100.0 & 0.00 \\
\hline Crude protein & $85.1^{\mathrm{c}}$ & $86.8^{\mathrm{b}}$ & $89.5^{a}$ & 0.82 \\
\hline \multicolumn{5}{|l|}{ Amino acids } \\
\hline \multicolumn{5}{|l|}{ Indispensable } \\
\hline arginine & $93.5^{b}$ & $94.2^{\mathrm{b}}$ & $96.4^{a}$ & 0.42 \\
\hline histidine & $91.2^{\mathrm{b}}$ & $91.7^{\mathrm{b}}$ & $94.5^{\mathrm{a}}$ & 0.56 \\
\hline isoleucine & $86.2^{b}$ & $88.2^{b}$ & $91.4^{a}$ & 0.93 \\
\hline leucine & $89.8^{\mathrm{b}}$ & $90.6^{\text {ab }}$ & $92.7^{\mathrm{a}}$ & 0.68 \\
\hline lysine & $86.7^{b}$ & $88.2^{\mathrm{h}}$ & $94.0^{\mathrm{a}}$ & 0.83 \\
\hline methionine & $77.4^{\mathrm{b}}$ & $81.5^{*}$ & $82.3^{\mathrm{a}}$ & 1.20 \\
\hline phenylalanine & $89.6^{b}$ & $90.5^{\mathrm{ab}}$ & $92.6^{4}$ & 0.69 \\
\hline threonine & $83.2^{b}$ & $85.1^{\mathrm{b}}$ & $89.3^{\mathrm{a}}$ & 1.08 \\
\hline valine & $86.4^{\mathrm{b}}$ & $88.2^{\mathrm{ub}}$ & $90.9^{4}$ & 0.94 \\
\hline \multicolumn{5}{|l|}{ Dispensable } \\
\hline alanine & $85.4^{b}$ & $86.9^{b}$ & $91.5^{\mathrm{a}}$ & 0.75 \\
\hline aspartic acid & $88.4^{\mathrm{b}}$ & $89.0^{\mathrm{b}}$ & $94.7^{\mathrm{a}}$ & 0.38 \\
\hline cysteine & 86.1 & 87.7 & 86.4 & 0.82 \\
\hline glutamic acid & 96.1 & 96.3 & 96.7 & 0.17 \\
\hline glycine & 86.6 & 87.4 & 89.0 & 1.00 \\
\hline serine & $90.3^{b}$ & $91.8^{\mathrm{b}}$ & $93.8^{\mathrm{u}}$ & 0.56 \\
\hline tyrosine & $88.9^{b}$ & $91.3^{\mathrm{ab}}$ & $93.3^{\mathrm{a}}$ & 0.91 \\
\hline
\end{tabular}

'refer to Table 1

${ }^{y}$ standard error of the mean

$\mathrm{a}, \mathrm{b}, \mathrm{c}-\mathrm{P}<0.05$

pearance was largest for aspartic acid, glutamic acid and glycine. There was net synthesis of methionine in the large intestine of pigs fed the W+SBM diet.

The apparent ileal amino acid digestibilities in ground and micronized wheat (Table 7) were determined with the difference method. Micronization improved the ileal digestibilities of all amino acids except for methionine and cysteine. Of the indispensable amino acids, the differences ranged from 2.2 (arginine) to 12.2 (threonine) percentage units; the differences were significant $(\mathrm{P}<0.05)$ for histidine, lysine, phenylalanine and threonine. Of the dispensable amino acids, the differences ranged from 4.9 (tyrosine) to 17.2 (glycine) percentage units; the differences were significant $(\mathrm{P}<0.05)$ for alanine, aspartic acid, glutamic acid, serine and tyrosine. 
TABLE 6

Disappearance' of dry matter, energy, starch, crude protein and amino acids in the large intestine of pigs fed the experimenta! diets

\begin{tabular}{|c|c|c|c|c|}
\hline \multirow[b]{2}{*}{ Item } & \multicolumn{4}{|c|}{ Diets ${ }^{y}$} \\
\hline & $W+S B M$ & $\mathrm{MW}+\mathrm{SBM}$ & $C+S B M$ & SEM $^{*}$ \\
\hline Dry matter & $215.3^{\mathrm{d}}$ & $174.4^{\mathrm{b}}$ & $166.7^{\mathrm{b}}$ & 11.95 \\
\hline Encrgy, $\mathrm{MJ} \mathrm{kg}^{-1} \mathrm{DMI}$ & $5.0^{\mathrm{a}}$ & $3.3^{b}$ & $2.8^{c}$ & 0.60 \\
\hline Starch & $39.6^{\mathrm{a}}$ & $4.8^{\mathrm{b}}$ & $9.1^{\mathrm{b}}$ & 3.42 \\
\hline Crude protein & 18.2 & 21.1 & 22.6 & 2.22 \\
\hline \multicolumn{5}{|l|}{ Amino acids } \\
\hline \multicolumn{5}{|l|}{ Indispensable } \\
\hline arginine & 0.66 & 0.47 & 0.53 & 0.08 \\
\hline histidine & $0.26^{\mathrm{a}}$ & $0.10^{\mathrm{b}}$ & $0.18^{\mathrm{ab}}$ & 0.03 \\
\hline isoleucine & 0.24 & 0.06 & 0.34 & 0.09 \\
\hline leucine & 0.82 & 0.36 & 0.85 & 0.14 \\
\hline lysine & $0.61^{\mathrm{a}}$ & $0.29^{b}$ & $0.70^{\mathrm{a}}$ & 0.10 \\
\hline methionine & -0.14 & 0.03 & 0.00 & 0.04 \\
\hline phenylalanine & $0.45^{\mathrm{a}}$ & $0.18^{\circ}$ & $0.46^{\mathrm{a}}$ & 0.09 \\
\hline threonine & $0.74^{\mathrm{a}}$ & $0.29^{\mathrm{b}}$ & $0.68^{\mathrm{a}}$ & 0.08 \\
\hline valine & 0.55 & 0.21 & 0.33 & 0.11 \\
\hline \multicolumn{5}{|l|}{ Dispensable } \\
\hline alanine & $0.72^{\mathrm{a}}$ & $0.30^{\mathrm{b}}$ & $0.58^{\mathrm{a}}$ & 0.09 \\
\hline aspartic acid & $1.19^{\mathrm{b}}$ & $0.63^{c}$ & $1.67^{\circ}$ & 0.14 \\
\hline cysteine & 0.37 & 0.48 & 0.36 & 0.07 \\
\hline glutamic acid & $3.40^{\mathrm{a}}$ & $1.43^{\mathrm{b}}$ & $2.66^{\mathrm{a}}$ & 0.07 \\
\hline glycine & $1.41^{\mathrm{a}}$ & $0.65^{\mathrm{b}}$ & $1.04^{\mathrm{ab}}$ & 0.19 \\
\hline serine & $0.76^{\mathrm{a}}$ & $0.44^{\mathrm{b}}$ & $0.69^{: 4}$ & 0.20 \\
\hline tyrosine & 0.36 & 0.23 & 0.30 & 0.05 \\
\hline
\end{tabular}

$\mathrm{g} \mathrm{kg}^{-1} \mathrm{DMI}$

${ }^{y}$ refer to Table 1

${ }^{x}$ standard error of the mean

a, b, c $-\mathrm{P}<0.05$

Micronization of wheat also improved $(\mathrm{P}<0.05)$ the ileal digestibility of starch from 93.1 to $99.3 \%$ (Table 7). The ileal digestibilities of starch in the $\mathrm{W}+\mathrm{SBM}$ and $\mathrm{MW}+\mathrm{SBM}$ diets (Table 4) were considered to be similar to ground and micronized wheat, respectively, for reasons that soyabean meal contributes only a negligible amount $(0.6 \%)$ of starch to the total dietary starch content. 
TABLE 7

Effect of micronization of wheat on the apparent ileal digestibilities of starch, crude protein and amino acids, \%

\begin{tabular}{llll}
\hline Item & $\mathrm{W}^{\prime}$ & $\mathrm{MW}^{\prime}$ & SEM $^{y}$ \\
\hline Starch & 93.1 & 99.3 & 0.71 \\
Crude protein & 73.6 & 75.3 & 1.92 \\
Amino acids & & & \\
Indispensable & & & \\
$\quad$ arginine & 80.3 & 82.5 & 1.05 \\
$\quad$ histidine & $79.4^{\mathrm{b}}$ & $85.8^{\mathrm{a}}$ & 0.59 \\
$\quad$ isoleucine & 80.1 & 83.9 & 1.08 \\
lcucine & 82.7 & 87.4 & 1.14 \\
lysine & $57.6^{\mathrm{b}}$ & $69.7^{\mathrm{a}}$ & 1.86 \\
methionine & 64.7 & 62.2 & 1.59 \\
phenylalanine & $81.7^{\mathrm{b}}$ & $87.0^{\mathrm{a}}$ & 0.98 \\
threonine & $64.7^{\mathrm{b}}$ & $76.9^{\mathrm{a}}$ & 1.54 \\
$\quad$ valine & 79.0 & 83.8 & 1.40 \\
Dispensable & & & \\
alanine & $69.5^{\mathrm{b}}$ & $78.1^{\mathrm{a}}$ & 1.49 \\
aspartic acid & $71.6^{\mathrm{b}}$ & $79.3^{\mathrm{a}}$ & 1.56 \\
cysteine & 70.0 & 66.6 & 3.56 \\
glutamic acid & $89.6^{\mathrm{b}}$ & $94.9^{\mathrm{a}}$ & 0.09 \\
glycine & 65.5 & 82.7 & 0.65 \\
serine & $80.0^{\mathrm{b}}$ & $85.5^{\mathrm{a}}$ & 0.93 \\
tyrosine & $73.0^{\mathrm{b}}$ & $77.9^{\mathrm{a}}$ & 0.92 \\
\hline
\end{tabular}

"refer to Table 2

${ }^{y}$ standard error of the mean

$\mathrm{a}, \mathrm{b}, \mathrm{c}-\mathrm{P}<0.05$

\section{DISCUSSION}

Infrared processing resulted in a slight decrease, from 76.9 to $74.4 \%$, in the content of starch in wheat (Table 2). McNeill et al. (1975) also reported a decrease in starch content, with a concomitant increase in the fraction of ethanol-soluble carbohydrates. In agreement with studies by Douglas et al. (1991) with maize and sorghum, micronization did not affect the content of the other parameters measured, including amino acids.

Micronization is a process in which infrared generators are used to heat cereal grains with or without pre-conditioning with water. This process will cause starch gelatinization, in which many of the starch granules are disrupted and adhere together forming sheets (Harbers, 1975).

The ileal and faecal digestibilities of energy as well as the ileal digestibility of starch were higher in the MW + SBM than W + SBM diet (Tables 4 and 5) which 
supports the results of studies in which micronization of sorghum and maize improved the in vitro availability of starch (Savage et al., 1980; Douglas et al., 1991). Starch granules of micronized sorghum were completely gelatinized and more susceptible to enzymatic degradation by $x$-amylase than starch of untreated ground sorghum (McNeill et al., 1975). Harbers (1975) showed that micronization disrupted the protein matrix surrounding starch granules thereby rendering starch more susceptible to enzymatic action.

With the exception of methionine and cysteine, the ileal digestibilities of amino acids were higher $(\mathrm{P}<0.05)$ in the $\mathrm{MW}+\mathrm{SBM}$ than $\mathrm{W}+\mathrm{SBM}$ diet (Table 4). With the exception of one study, there is no information in the literature on the effect of micronization on protein digestibility. There is no information on amino acid digestibility. Hafez et al. (1985) showed that microwave heating of soyabean for $9 \mathrm{~min}$ increased the true protein digestibility in rats from 73 to $84 \%$. Furthermore, the results of the present study are in agreement with studies in which other heat-processing methods were used. Hsu et al. (1977) reported that heating improved the digestibility of seed protein by destroying protein inhibitors and opening the structure through denaturation. Rooney et al. (1986), in studies with sorghum, suggested that cooking increased the solubility of protein in general and that of the prolamin proteins in particular. Furthermore, baking increased the ileal digestibility of $\mathrm{CP}$ (also of starch and dietary fibre) of a hulless barley-based diet fed to pigs (Fadel et al., 1989).

As was reported in previous studies, the ileal compared with the faecal analysis method is more sensitive for detecting differences in amino acid digestibilities as these result from different processing methods (e.g., Sauer et al., 1977; van Weerden et al.,1985). These studies show once more the modifying and apparent equalizing effect of the microflora in the large intestine on amino acid digestibility values.

The disappearance of dry matter, energy and starch in the large intestine was lower $(\mathrm{P}<0.05)$ in pigs fed the $\mathrm{MW}+\mathrm{SBM}$ than $\mathrm{W}+\mathrm{SBM}$ diet (Table 6). Micronization shifted the disappearance of energy from the large to the small intestine. This shift should result in an improvement in the efficiency of energy utilization as was shown by Just et al. (1983) in studies with pigs fed diets with different fibre content. A one percent increase in the proportion of energy disappearing in the large intestine decreased the utilization of metabolizable energy by $0.8 \%$ (Just et al., 1983). According to Bergman (1990), as much as 25 to $40 \%$ of the potential energy content of carbohydrates entering the large intestine was used for microbial processes or lost as methane. The increase in the efficiency of energy utilization in this study would be small. The ileal energy digestibility in wheat was relatively high to start with $93.1 \%$ (Tables 3-7). Micronization would be expected to have a larger effect in cereals, for example barley, in which the ileal energy digestibility is lower ( $\mathrm{Li}$ et al., 1996). Starch escaping digestion in the small 
intestine of pigs fed the experimental diets was completely fermented in the intestine, which was also reported by Sauer et al. (1977) in studies with wheat and by Fadel et al. (1989) in studies with hulless barley.

There was a larger disappearance of the total of the dispensable than indispensable amino acids (Tables 3-6), which was previously discussed by Li et al. (1994). There was net synthesis of methionine in the large intestine of pigs fed the $\mathrm{W}+$ SBM diet. Net synthesis of methionine has also been reported in other studies (e.g., Li and Sauer, 1994).

The apparent ileal digestibilities of amino acids in ground and micronized wheat (Tables 3-7) were determined with the difference method. Fan and Sauer (1995) showed that amino acid digestibilities in ingredients low in CP (amino acid) content should be determined with the difference rather than direct method which was illustrated in studies with barley that contained $11.4 \% \mathrm{CP}$. Of the indispensable amino acids, digestibility values in barley were lower when these were determined with the direct method, ranging from 2.3 (histidine) to 9.1 (threonine) percentage units. The CP content of wheat in this study was $11.5 \%$. As was pointed out by Fan et al. (1994), the apparent digestibility values of amino acids in a feedstuff are dependent on their respective amino acid levels and reach a plateau when their threshold levels are reached. Threshold levels in feedstuffs low in amino acid content can only be reached when the difference method is used.

Micronization improved the apparent ileal digestibilities of most of the amino acids in wheat (Table 7). As has been reported in many other studies, of the indispensable amino acids, the digestibilities of lysine and threonine were relatively low, 57.6 and $69.7 \%$ for lysine, and 64.7 and $76.9 \%$ for threonine in ground and micronized wheat (Table 7), respectively. The probable reasons for the relatively low lysine digestibility in wheat were reviewed by Mosenthin et al. (1997). The digestibility values of lysine and threonine, first and second limiting in protein in wheat, respectively, fall within the range of values reported by Mosenthin et al. (1997). These authors reported digestibility values of $73( \pm 6.5)$ and $72( \pm 6.7) \%$ for lysine and threonine, respectively. In the same order for these amino acids, the minimum and maximum values ranged from 62 to 84 and 51 to $78 \%$, respectively. Furthermore, the considerable variation in amino acid digestibility values in wheat results from several factors, including fineness of grinding, as was reviewed by Sauer and Ozimek (1986). In addition, digestibility values are affected by method of determination i.e. the direct versus difference method (Fan and Sauer, 1994); the direct method was used in nearly all studies reported in the literature. Furthermore, BW (age) may affect digestibility values (Li et al., 1993; Li and Sauer, 1994). The present studies were carried out with pigs over the BW range from 7.0 to $16.5 \mathrm{~kg}$. Most studies on wheat have been carried out with growing and finishing pigs. 
Micronization of wheat improved $(\mathrm{P}<0.05)$ the lysine digestibility from 57.6 to $69.7 \%$ (Table 7), which indicates indirectly that Maillard reactions did not occur. According to Noguchi et al. (1982) and Björck et al. (1983), a high moisture content during heat-processing will inhibit Maillard reactions and improve lysine digestibility, which can be explained by the law of mass action, as water is produced in the reversible phase of Maillard reactions.

In conclusion, micronization of wheat improved the ileal digestibilities of most of the amino acids, including lysine and threonine. Micronization also shifted the disappearance of starch from the large to the small intestine, which may result in an improvement in the efficiency of energy utilization.

\section{AKNOWLEDGMENTS}

The authors are grateful for financial support provided by the Alberta Barley Commission and the Saskatchewan Development Corporation. Furthermore, the authors would like to thank Brenda Tchir and Charlane Gorsak for assistance with surgery and care of the animals.

\section{REFERENCES}

AOAC, 1990. Official Methods of Analysis of the Association of Official Analytical Chemists. 15th Edition, Artington, VA, USA

Bengala-Freire J., Peiniau J., Lebreton Y., Aumaitre A., 1988. Determination of ileal digestibility by shunt technique in the early-weaned pig: Methodological aspects and utilisation of starch rich diets. Livest. Prod. Sci. 20, 233-247

Bergman E.N., 1990. Energy contributions of volatile fatty acids from the gastrointestinal tract in various species. Physiol. Rev. 70, 567-590

Björck I., Asp N. G., 1983. The effects of extrusion cooking on nutritional value - A literature review. J. Food Eng. 2, 281-308

Björck I., Asp N. G.. 1984. Protein nutritional value of extrusion-cooked wheat flours. Food Chem. $15,203-214$

Björck I., Asp N. G., Birkhed D., Lundquist 1., 1984a. Effect of processing on availability of starch for digestion in vitro and in vivo; I. Extrusion cooking of wheat flour and starch. J. Cereal Sci. 2, 91-103

Björck I., Asp N. G., Birkhed D., Eliasson A. G., Sjöberg L. B., Lundquist I., 1984b. Effect of processing on starch availability in vitro and in vivo: II. Drum-drying of wheat flour. J. Cereal Sci. $2,165-178$

Björck I., Noguchi A.. Asp N. G., Cheftel J. C., Dahlqvist A., 1983. Protein nutritional value of a biscuit processed by extrusion cooking: Effects on available lysine. J. Agric. Food Chem. 31. 488-492

CCAC, 1984. Guide to the Care and Use of Experimental Animals. Vol. 1 (with addendum). Canadian Council on Animal Care, Ottawa, ON, Canada 
Douglas J. H., Sullivan T. W., Abdul-Kadir R., Rupnow J. H., 1991. Influence of infrared (micronization) treatment on the nutritional value of corn and low-and high-tannin sorghum. Poultry Sci. 70, 1534-1539

Dugan M. E. R., Sauer W. C., Fenton T. W., 1992. A vortex vacuum evaporator for samples in test tubes. Can. J. Anim. Sci. 72, 189-192

Fadel J. G., Newman R. K.. Newman C. W., Graham H., 1989. Effect of baking hulless barley on the digestibility of dietary components as measured at the ileum and in the faeces in pigs. $J$. Nutr. $119,722-726$

Fan M.Z.. Sauer W.C., 1995. Determination of apparent ileal amino acid digestibility in barley and canola meal for pigs with the direct, difference, and regression methods. J. Anim. Sci. 73, 2364-2374

Fan M. Z., Sauer W. C., Hardin, R. T., Lien K. A., 1994. Determination of apparent ileal amino acid digestibility in pigs: effect of dietary amino acid level. J. Anim. Sci. 72, 2581-2859

Fenton T.W., Fenton M., 1979. An improved procedure for the determination of chromic oxide in feed and faeces. Can. J. Anim. Sci. 59,631-634

Goering H. K., van Soest P. J., 1970. Forage Fibre Analysis (Apparatus, Reagents, Procedures, and some Application). Agriculture Handbook No. 379. ARS, USDA, Washington, DC

Hafez Y. S., Mohamed A. 1., Hewedy, F. M., Singh G., 1985. Effect of microwave heating on solubility, digestibility and metabolism of soy protein. J. Food Sci. 50, 415-417

Harbers L. H., 1975. Starch granules structural changes and amylolytic patterns in processed sorghum grain. J. Anim. Sci. 41, 1496-1501

Hsu H. W., Vavak D. L., Satterlee L. D., Miller G. A. A., 1977. Multienzyme technique for estimating protcin digestibility. J. Food Sci. 42, 1269-1273

Jideani A. I., Apenten R. K. O., Muller H. G., 1994. The effect of cooking on proteins from Acha (Digitaria exilis) and Durum wheat. J. Sci. Food Agric. 65, 465-476

Jones B. N., Gilligan J. P., 1983. $\omega$-phthaldialdehyde precolumn derivitization and reversephase high performance liquid chromatography of polypeptide hydrolysates and physiological fluids. J. Chromatogr. 266, 471-482

Just A. J., Fernandez A., Jørgensen H., 1983. The net energy value of diets for growth in pigs in relation to the fermentative process in the digestive tract and site of absorption of the nutrients. Livest. Prod. Sci. 10, 171-186

Li S., Sauer W. C., 1994. The effect of dietary fat content on amino acid digestibility in young pigs. $J$. Anim. Sci. 72. 1737-1743

Li S., Sauer W. C., Hardin R. T., 1994. Effect of dictary fibre level on amino acid digestibility in young pigs. Can. J. Anim. Sci. 74, 327-333

Li S., Sauer W.C., Huang S.X., Gabert V.M. 1996. Effect of $\beta$-glucanase supplementation to barley or wheat soyabean meal diets on the digestibility of energy, protein, $\beta$-glucans and amino acids in young pigs. J. Anim. Sci. 74, 1649-1656

McNeill J. W., Potter G. D., Riggs J. K., Rooncy L. W., 1975. Chemical and physical propertics of processed sorghum grain carbohydrate. J. Anim. Sci. 40, 335-341

Mosenthin R., Rademacher M., Sauer W. C., 1997. Zur praezäkalen Aminosäurenverdaulichkeit in Futtermitteln für Schweine. Z. Übers. Tierernähr. (in press)

NRC, 1988. Nutrient Requirements of Swine. 9th Edition. National Academy Press, Washington, DC

Noguchi A., Mosso A. W., Seiler K., Fretzdorff J., 1982. Maillard reactions during extrusion cooking of protein-enriched biscuits. Lebensm. Wiss. Technol. 15 (2), 105-110

Rooncy L.W., Kirleis A. W., Murty D. S., 1986. Traditional foods from sorghum: their production, cvaluation and nutritional valuc. Adv. Cereal Sci. Technol. 8, 317-353 
Rooney L. W., Pflugfelder R. L., 1986. Factors affecting starch digestibility with special emphasis on sorghum and corn. J. Anim. Sci. 63, 1607-1623

SAS, 1990. SAS/STAT $\left.{ }^{(}\right)$Users Guide (Release 6.03). SAS Institute Inc., Cary, NC, USA

Savage G. P., Smith W. C., Briggs P. A., 1980. A note on the influence of micronization and polycthylene glycol on the nutritional value of brown sorghum for growing pigs. Anim. Prod. 30, $157-160$

Sauer W. C., Ozimek L., 1986. Digestibility of amino acids in swine: Results and their practical application. A review. Livest. Prod. Sci. 15, 367-388

Sauer W. C., Stothers S. C., Phillips G. D., 1977. Apparent availabilities of amino acids in corn, wheat and barley for growing pigs. Can. J. Anim. Sci. 57, 585-597

Sedgwick G., Fenton T.W., Thompson J. R., 1991. Effect of protein precipitating agents on the recovery of plasma free amino acids. Can. J. Anim. Sci. 71, 953-957

Weerden E. J. van, Huisman J., Leeuwen van P., Slump P., 1985. The sensitivity of ileal digestibility method as compared to the faecal digestibility method. In: A. Just, H. Jørgensen, J. A. Fernandez (Editors). Proceedings of $3^{\text {rd }}$ International Seminar on Digestive Physiology of the Pig, Kollekolle (Denmark), pp. 392-396

\section{STRESZCZENIE}

\section{Wpływ mikronizacji drobno zmielonego ziarna pszenicy na strawność energii, skrobi i aminokwasów u mlodych świń}

Sześć prosiąt (Canabrid x Camborough) odsadzono w 21 dniu życia, a w 23 i 24-tym założono im kaniule typu-T do koncowego odcinka jelita biodrowego. Prosięta żywiono jedną z trzech dawek: zmielone ziarno pszenicy + śruta sojowa, zmielone ziarno pszenicy poddane działaniu mikrofalowemu + śruta sojowa lub skrobia kukurydziana + śruta sojowa, w układzic kwadratu lacińskiego. Dzienne dawki pasz, z domieszką trójtlenku chromu jako wskaźnika, w ilości 5\% masy ciała podzielono na trzy jednakowe porcje i podawano zwierzętom co 8 godz. Masa ciała prosiąt na poc7ąt ku doświadczenia wynosiła $9,2 \mathrm{~kg}$, a na końcu $16,5 \mathrm{~kg}$. Kał zbierano przez 48 godzin 6 i 7 dnia doświadczenia, a treść jelita przez 24 godz, w dniu 8 i 9. Pozorną strawność jelitową aminokwasów (do końca jelita cienkiego) pszenicy zmielonej i poddancj działaniu mikrofalowemu oznaczano metodą różnicową. Pozorna strawność jelitowa aminokwasów niezbędnych byla większa dla pszenicy poddanej działaniu mikrofalowemu niż tylko zmielonej. od 2,2 jcdnostck procentowych dla argininy do 12,2 trconiny. Różnice w strawności były istotne $(\mathrm{P}<0,05)$ dla histydyny, lizyny, fenyloalaniny i treoniny. Działanie mikrofalowe na pszenicę poprawiło istotnie $(\mathbf{P}<0,05)$ strawność jelitową skrobi z 93,1 do $99,3 \%$, a także wpłynęło na 7 większenic trawienia i wchłaniania energii w jelicie cienkim i obniżylo fermentację składników energetycznych w jelicie grubym.

Wyniki badań wskazują na dodatni wpływ działania mikrofalowcgo na strawność energii i aminokwasów pszenicy przez młode świnie. 